\title{
Geometric accuracy of topographical objects at Polish topographic maps
}

\author{
Radzym Lawniczak, Jarosław Kubiak \\ Adam Mickiewicz University in Poznań \\ Faculty of Geographical and Geological Sciences \\ Department of Cartography and Geomatics \\ 27 Dzięgielowa St., 61-680 Poznań \\ e-mail: radzym@amu.edu.pl,jkubiak@amu.edu.pl
}

Received: 23 May 2015 / Accepted: 8 October 2015

\begin{abstract}
The objective of research concerned verifying the accuracy of the location and shape of selected lakes presented on topographical maps from various periods, drawn up on different scales. The area of research covered lakes situated in NorthWestern Poland on the Międzychód-Sieraków Lakeland. An analysis was performed of vector maps available in both analogue and digital format. The scales of these studies range from 1:50 000 to 1:10 000. The source materials were current for the years 1907 through 2013. The shape and location of lakes have been verified directly by means of field measurements performed using the GPS technology with an accuracy class of RTK. An analysis was performed of the location and shape of five lakes. The analysed water regions were vectorised, and their vector images were used to determine quantitative features: the area and length of the shoreline. Information concerning the analysed lakes obtained from the maps was verified on the basis of direct field measurements performed using a GPS RTK receiver. Use was made of georeferential corrections provided by the NAVGEO service or a virtual reference station generated by the ASG EUPOS system. A compilation of cartographic and field data formed the basis for a comparison of the actual area and the length of the shoreline of the studied lakes. Cartographic analyses made it possible to single out the most reliable cartographic sources, which could be used for the purposes of hydrographical analyses. The course of shorelines shows the attached map.
\end{abstract}

Keywords: cartographic analysis, accuracy of maps, topographical maps

\section{Introduction}

Cartographical documentation elaborated in the form of topographical maps - both analogue and numerical - is finding ever wider application. Such maps are commonly used, among others, to catalogue natural resources (including aquatic), assess natural conditions, and also in design and planning work. Furthermore, they are used as an administrative support tool. For this reason, the geometric accuracy of objects 
presented on these maps is an important issue. This concerns both the technical infrastructure, and natural elements, among others the hydrographic grid, terrain forms, etc. Obviously, one must be aware of the fact that the geometric accuracy of a topographical map is always the resultant of a great many different factors - the scale, print quality, condition of the data carrier, conditions of storage, and - finally - the diligence of the topographer and cartographer.

\section{Objective and area of research}

The research focused, among others, on comparing objects presented on topographical maps with their counterparts in the field. The topographical objects constituting the subject of research were lakes located in North-Western Poland, north of the town of Międzychód. All of the lakes are postglacial flowing water reservoirs (moraine lakes). Customarily, these lands are known as the Międzychód-Sieraków Lakeland (Figure 1). The study included location of the shoreline of lakes:

- Gtęboczek Lake,

- Mierzyńskie Lake,

- Mtyńskie Lake,

- Radgoskie Lake,

- Szenińskie Lake.

The lakes selected for the research are characterised by a relatively accessible and distinct shoreline. Neither the shorelines, nor the areas neighbouring directly upon the lakes show any significant anthropogenic changes. An exception are the surroundings of Lake Mierzyńskie, which have been closely built up with holiday cottages. The locations of the researched lakes have been presented at attached map.

Measurements were performed during summer, at the end of June and beginning of July, in the years 2011-2013. In the course thereof, references were made to the currently existing hydrological situation, which impacted the height of the water table, and thus the range of lakes' surfaces. However, annual observations of the state of these water reservoirs, performed by the authors over the past 20 years, allow us to state that due to the shape of the shoreline, changes in the surface of the water table were not significant in relation to the existing hydrological conditions. Higher water tables do not significantly impact the course of the shoreline. In addition, the studied water reservoirs do not have any water-level measurement points, nor are they the object of regular hydrological observations. 


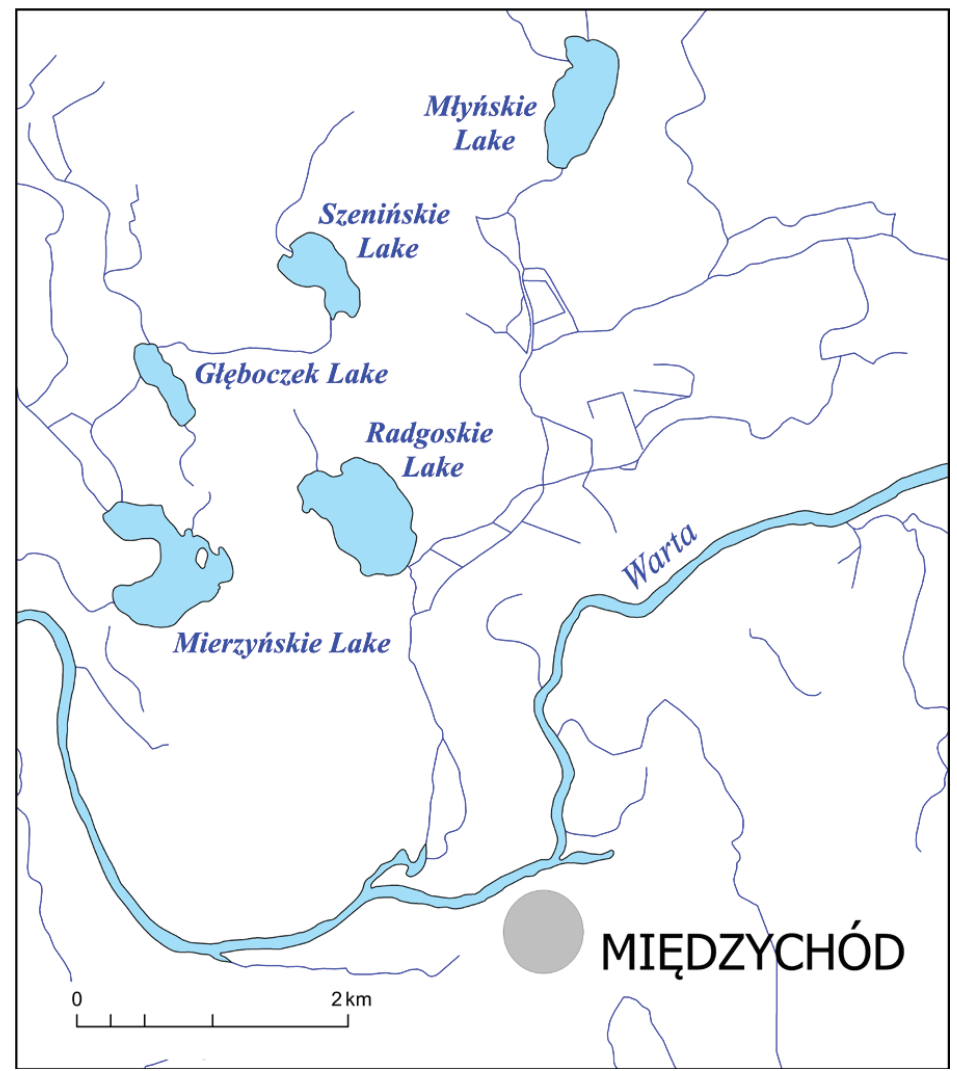

Fig. 1. Research area and selected lakes of the Międzychód-Sieraków Lakeland

\section{Source materials}

The region constituting the subject of research has been presented on numerous topographical maps drawn up on many different scales, and these are current for the years 1907 through 2013. Hydrometric data from other publications were also compared. Use the following analogue map source (in parentheses are the year of publication):

- Topographische Karte 1:25 000 (1940)

- Topographic Map 1:25 000 (1964)

- Topographic Map 1:50 000 „coordinates system 1965” (1977)

- Topographic Map 1:10 000 „coordinates system 1965” (1991)

- Topographic Map 1:50 000 „,coordinates system 1992” (1998)

Use was also made of a topographical map drawn up on a scale of 1:100 000, sheet 38-22 Międzychód from 1934, however due to its scale it was not utilised in subsequent comparative work. 
Also compared the location of the shoreline of a digital topographic and thematic maps:

- Sozological Map „coordinates system 1992” (2002),

- MPHP - Map of Hydrographic Division of Poland (1997 - 2003),

- VMapL2 - Vector Map Level 2 - digital map of the NATO standard (2003),

- Hydrographic Map „,coordinates system 1992” (2005),

- BDOT - Topographic Database Objects „,coordinates system 1992” (2013).

The level of detail of these studies corresponds to that of a topographical map drawn up on a scale of 1:50 000, BDOT 1:10 000.

Finally, hydrometric data from the Katalog jezior Polski (Catalogue of Polish Lakes) by Choiński (2006) and the Atlas jezior Polski (Atlas of Polish Lakes), ed. Jańczak (1996), were also used. The results of direct field measurements performed by the authors in the years $2011-2013$ were used for comparative purposes.

\section{Research methods}

The first stage of work was concerned with the collection of cartographic source materials concerning the researched area, both on traditional and electronic data carriers. The analogue maps were scanned and calibrated so as to avoid possible distortions caused by the condition of the base-map. In order to enable a comparison of the quantitative features of the researched objects, all of the maps were given georeferences under the geodetic coordinate system currently in force in Poland (PUWG - National Geodetic Coordinate System - 1992). Georeferences were given on the basis of map control points, the location of which was verified in the field. The georeferences of control points were determined on the basis of differential GPS measurements.

The next stage was field work, which consisted in the direct measurement of the studied water reservoirs; differential GPS measurements were performed, while maintaining the RTK (Real Time Kinematic) class level of accuracy. This is the most precise kinematic technique, for it yields a centimetre or - under favourable conditions - millimetre -accuracy. However, its disadvantage consists in the fact that performing measurements in heavily forested areas is difficult (Rogowski and Kłęk, 2009).

Measurements were carried out using a GPS RTK Hyper Pro receiver manufactured by Topcon. During measurements, the receiver's antenna was placed on the shorelines of the respective lakes, at points spaced 3 to $5 \mathrm{~m}$ apart. The location of the antenna was frequently conditioned by the vegetation growing along the shore. Measurements were performed at a "fixed" horizontal placement accuracy level, which is characterised by the greatest precision. RTK measurements are satellite phase measurements, where the position determined by the mobile receiver is corrected in real time, with the utilisation of observational data sent from the base station, which makes it possible to obtain centimetre accuracy. In order to attain this level of precision, 
use was made of georeferential corrections provided by the Active Geodetic Network EUPOS (ASG EUPOS), which forms part of an international project. In Poland, the system comprises 98 fixed stations located uniformly throughout the country (Banasik et al., 2011).

Research utilised both corrections from individual stations, and VRS (Virtual Reference Station) corrections. The VRS is an integrated system, the components of which are used to model errors in a specific region, and subsequently create a virtual fixed station located at the point of interest; it transmits measurement corrections in real time to a mobile receiver (Rogowski and Kłęk, 2009). The studied area is located on the outer limits of the range of georeferential stations of the ASG system (range of georeferential stations up to $40 \mathrm{~km}$ ). More than once, this resulted in difficulties with receiving georeferential corrections, which were additionally impacted by the land configuration and the dense and tall arboreal vegetation in the direct vicinity of shorelines. In these instances, the authors set up independent georeferential stations at points with known coordinates. The range of such correction emitting stations was $2-3 \mathrm{~km}$, and proved fully sufficient in the course of measurements.

\section{Research results}

Data concerning the actual areas and lengths of shorelines, obtained from various studies, have been presented in Tables 1 and 2. This information was supplemented by the results of direct field measurements, conducted by means of precise satellite geodetic equipment. An analysis of the results obtained does not allow us to unequivocally select the "best" analogue topographical map. All the areas and shoreline lengths determined on the basis thereof differ from the values obtained through direct field measurements. From amongst the numerical maps, the most precise parameters concerning the range of the water surface and the length of the shoreline, as well as the location and shape of the object, were obtained using the BDOT (2013). The remaining digital materials were characterised by a lesser degree of accuracy in comparison with analogue maps. Tables 1 and 2 also presented percentage differences between values of areas and lengths of shorelines, obtained on the basis of field measurements. 


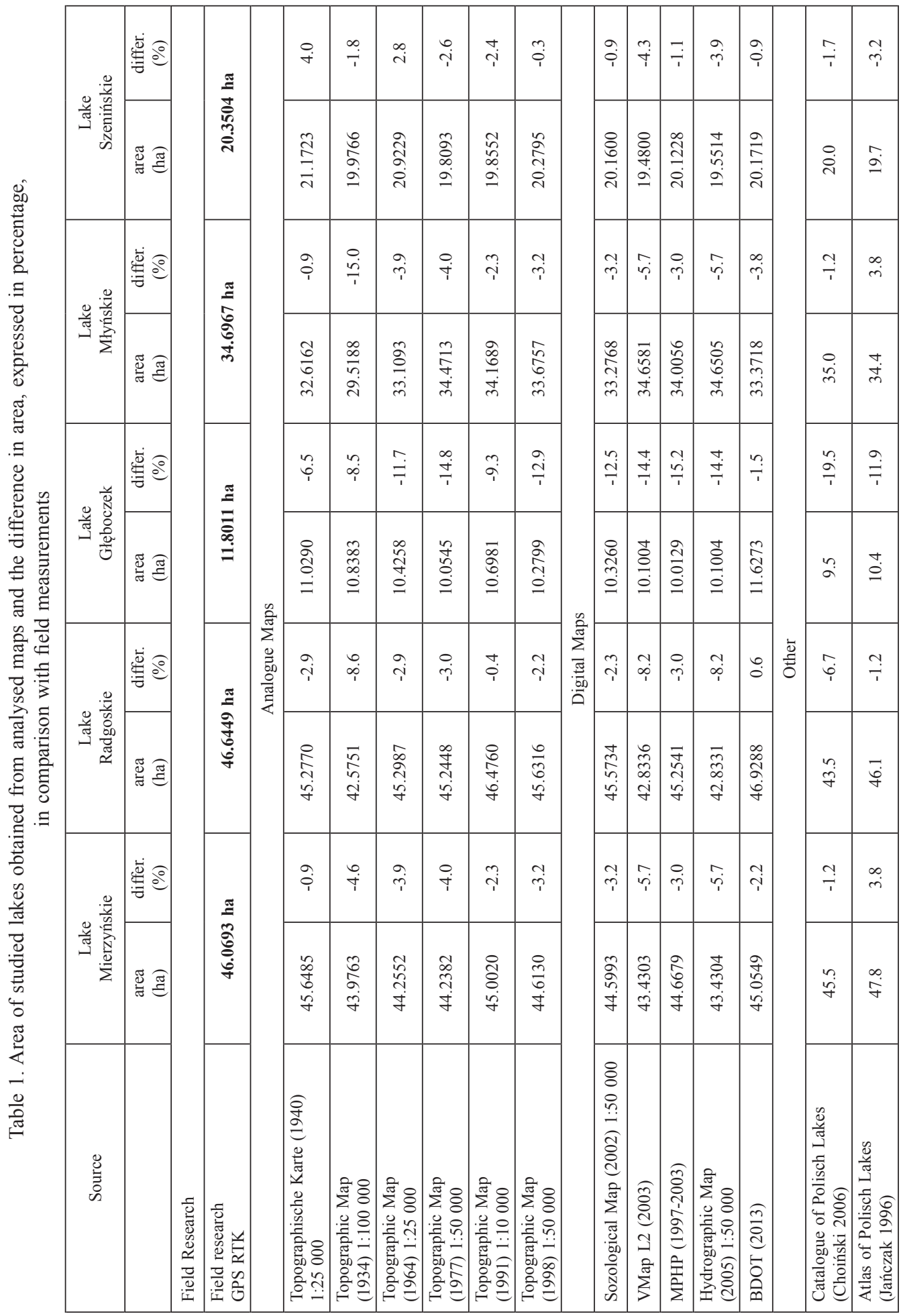




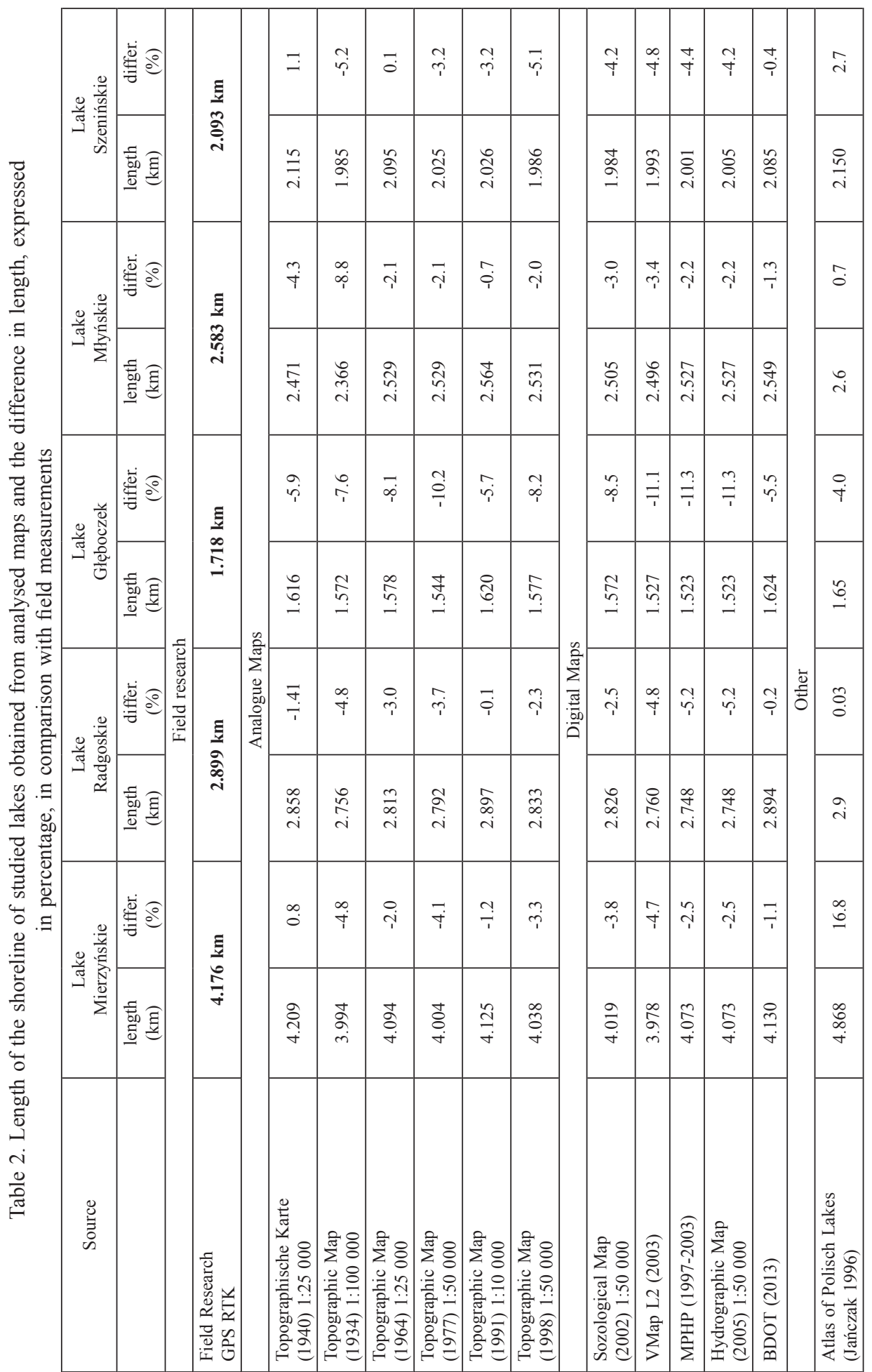


The data obtained by the field measuring a much more accurate calculation of the lake morphometric indicators than in the case of data obtained from the maps. One commonly used indicator is the parameter characterizing the degree of development of the shoreline. It is expressed as the not nominated number $(K)$ equal to or greater than 1 . The $K$ factor higher, the degree of development of the shoreline is greater. The factor is expressed by the formula:

$$
K=\frac{L}{2 \sqrt{\pi P}}
$$

$L$ - length of the shoreline,

$P$ - surface area of the lake

The results of calculations the $K$ factor presented in Table 3. Assuming that the indicator calculated based on the field research is the best, it can be concluded that the most faithfully mapped is BDOT (2013), Topographic Map 1:10 000 (1991) and Topographic Map 1:25 000 (1964). Best developed is the shoreline Mierzyńskie Lake, least Radgoskie Lake.

Table 3. The value of factor develop the shoreline $(K)$, based on the field research and cartographic analysis

\begin{tabular}{|c|c|c|c|c|c|}
\hline Source & $\begin{array}{c}\text { Lake } \\
\text { Mierzyńskie }\end{array}$ & $\begin{array}{c}\text { Lake } \\
\text { Radgoskie }\end{array}$ & $\begin{array}{c}\text { Lake } \\
\text { Głęboczek }\end{array}$ & $\begin{array}{l}\text { Lake } \\
\text { Młyńskie }\end{array}$ & $\begin{array}{c}\text { Lake } \\
\text { Szenińskie }\end{array}$ \\
\hline & $(K)$ factor & $(K)$ factor & $(K)$ factor & (K) factor & $(K)$ factor \\
\hline \multicolumn{6}{|c|}{ Field research } \\
\hline $\begin{array}{l}\text { Field Research } \\
\text { GPS RTK }\end{array}$ & 1.74 & 1.20 & 1.41 & 1.24 & 1.31 \\
\hline \multicolumn{6}{|c|}{ Analogue Maps } \\
\hline $\begin{array}{l}\text { Topographische Karte } \\
\text { (1940) 1:25000 }\end{array}$ & 1.76 & 1.20 & 1.37 & 1.22 & 1.30 \\
\hline $\begin{array}{l}\text { Topographic Map } \\
\text { (1934) 1:100 } 000\end{array}$ & 1.70 & 1.19 & 1.35 & 1.23 & 1.25 \\
\hline $\begin{array}{l}\text { Topographic Map } \\
\text { (1964) 1:25 } 000\end{array}$ & 1.74 & 1.18 & 1.38 & 1.24 & 1.29 \\
\hline $\begin{array}{l}\text { Topographic Map } \\
\text { (1977) 1:50 } 000\end{array}$ & 1.70 & 1.17 & 1.37 & 1.22 & 1.28 \\
\hline $\begin{array}{l}\text { Topographic Map } \\
\text { (1991) 1:10 } 000\end{array}$ & 1.73 & 1.20 & 1.40 & 1.24 & 1.28 \\
\hline $\begin{array}{l}\text { Topographic Map } \\
\text { (1998) 1:50 } 000\end{array}$ & 1.71 & 1.18 & 1.39 & 1.23 & 1.24 \\
\hline
\end{tabular}




\begin{tabular}{|l|c|c|c|c|c|}
\hline \multicolumn{1}{|c|}{ Source } & $\begin{array}{c}\text { Lake } \\
\text { Mierzyńskie }\end{array}$ & $\begin{array}{c}\text { Lake } \\
\text { Radgoskie }\end{array}$ & $\begin{array}{c}\text { Lake } \\
\text { Głęboczek }\end{array}$ & $\begin{array}{c}\text { Lake } \\
\text { Młyńskie }\end{array}$ & $\begin{array}{c}\text { Lake } \\
\text { Szenińskie }\end{array}$ \\
\hline & $(K)$ factor & $(K)$ factor & $(K)$ factor & $(K)$ factor & (K) factor \\
\hline \multicolumn{5}{|c|}{ Digital Maps } \\
\hline $\begin{array}{l}\text { Sozological Map } \\
\text { (2002) 1:50 000 }\end{array}$ & 1.70 & 1,18 & 1.38 & 1.22 & 1.25 \\
\hline VMap L2 (2003) & 1.70 & 1,19 & 1.36 & 1.20 & 1.27 \\
\hline MPHP (1997-2003) & 1.72 & 1.15 & 1.36 & 1.22 & 1.26 \\
\hline $\begin{array}{l}\text { Hydrographic Map } \\
\text { (2005) 1:50 000 }\end{array}$ & 1.74 & 1.18 & 1.35 & 1.21 & 1.28 \\
\hline BDOT (2013) & 1.74 & 1.19 & 1.34 & 1.24 & 1.31 \\
\hline
\end{tabular}

The attached figures 2 and 3 can also conclude that the shape of the different tested objects specified on the basis of digitalization and measurement field. Visualized with an example at one of the lakes (Lake Gtęboczek). This map shows an example of
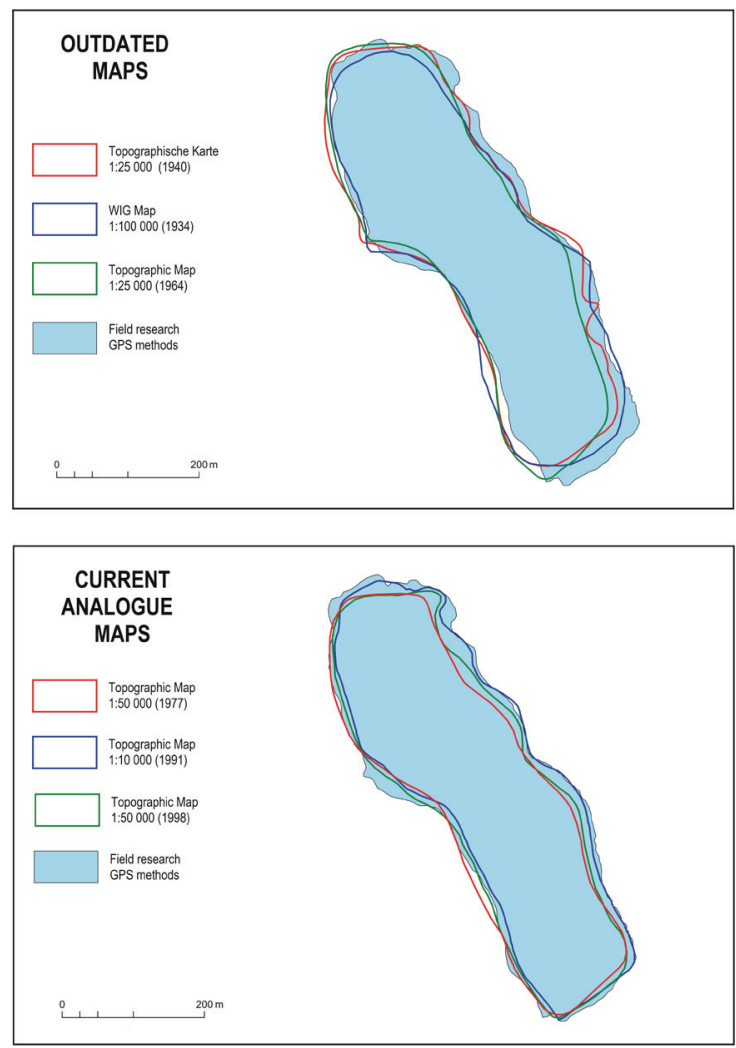

Fig. 2. The shoreline of Głęboczek Lake on the analogue maps 
the course of the shoreline of Lake Gtęboczek generated on the basis of all available cartographic materials broken down into analogue (Fig. 2) and numerical sources (Fig. 3). These were superimposed on the area of the lake obtained through direct field measurements, performed using equipment with an accuracy class of RTK, i.e. assuming the high precision of research.
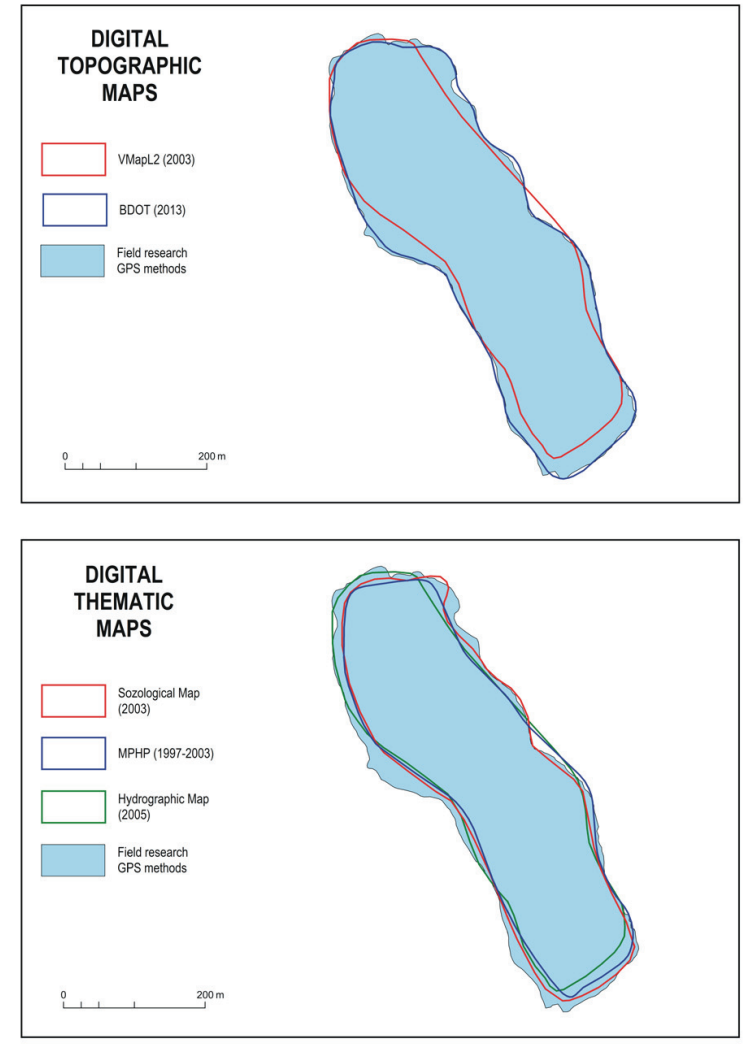

Fig. 3. The shoreline of Głęboczek Lake on the digital maps

\section{Summary and conclusions}

The range of the water table for selected lakes of the Międzychód-Sieraków Lakeland was determined using a GPS RTK receiver. This item of equipment is by far the most practical when performing detailed geodetic measurements (Kosiński, 2011). The measurements performed were used to verify the accuracy of available topographical maps. Furthermore, they have made it possible to obtain very precise quantitative data.

Furthermore, the referenced works did not touch upon the impact of cartographic generalisation, used in the process of elaborating source materials, on the qualitative 
and quantitative parameters obtained in the course of field measurements. According to Saliszczew (2003), during the process of cartographic generalisation there appear contradictions between obtaining the precise geometric location of objects and geographical conformity. Using the topographical maps drawn up on scales of 1:10 000 to 1:200 000, a compromise is sought between the correctness of the geometric placement of objects on maps and geographical faithfulness (MedyńskaGulij, 2011).

The visible shifts of the shoreline and differing values of lake areas may therefore be the result of the following:

- errors occurring during field work upon development of a given edition of maps (contemporary measurement tools are characterised by incomparably greater accuracy),

- intentional editing following from the map generalisation process,

- fluctuations in water table height, which should not however impact the image of a given lake on maps drawn up on a scale of 1:10 000 and smaller.

The measurements were conducted primarily in order to present opportunities for using differential measurement methods for updating and verifying existing cartographic materials, including those pertaining to the surface water grid. Thanks to the possibility of exporting data to various formats supported by the GIS software, one may more or less rapidly and easily visualise collected data and prepare materials for analysis and, if required, printing. Due to the limited availability of the most upto-date topographical materials, measurements may be used for the rapid updating of maps. Height measurements are another optional application.

\section{Acknowledgments}

This study has been financed by Institute of Physical Geography and Environmental Planning.

\section{References}

Banasik, P., Cichociński, P., Czaja, J., Góral, W., Kozioł, K., Krzyżek, R., Kudrys, J., Ligas, M. and Skorupa, B. (2011). Podstawy geomatyki. Wydawnictwa AGH. Kraków.

Choiński, A. (2006). Katalog jezior Polski. Wydawnictwo Naukowe UAM. Poznań.

Kosiński, W. (2011). Geodezja. Wydawnictwo Naukowe PWN. Warszawa.

Medyńska-Gulij, B. (2011). Kartografia i geowizualizacja. Wydawnictwo Naukowe PWN. Warszaw.

Rogowski, J. B. and Kłęk, M. (2009). Geodezja satelitarna. Uczelnia Warszawska im. Marii SkłodowskiejCurie. Warszawa.

Saliszczew, K. A. (2003). Kartografia ogólna. Horodyski B. (ed.), wyd. 3. PWN. Warszawa.

Maps and Atlases

Topographische Karte 1:25 000 (1940), sheet 3361 Birnbaum. Reichsamt für Landesaufnahme. Berlin.

Topographic Map (Mapa topograficzna) 1:100 000 (1934). Arkusz P38 S22, WIG. Warszawa. 
Topographic Map (Mapa topograficzna) 1:25 000 (1964). Powiat Międzychód, Zarząd Topograficzny Sztabu Generalnego. Warszawa.

Topographic Map of Poland (Mapa topograficzna Polski) 1:10 000 (1991). Arkusze: 411.422 Piłka; 411.424 Muchocin; 412.311 Zatom Nowy; 412.313 Międzychód. Główny Urząd Geodezji i Kartografii. Warszawa.

Topographic Map of Poland (Mapa topograficzna Polski) 1:50 000 (1977). Arkusze: 411.4 Skwierzyna, 412.3 Sieraków. Główny Urząd Geodezji i Kartografii. Warszawa.

Topographic Map of Poland (Mapa topograficzna Polski) 1:50 000 (1998). Arkusz N-33-128-B Międzychód. Główny Urząd Geodezji i Kartografii. Warszawa.

Sozological Map of Poland (Mapa Sozologiczna Polski) 1:50 000 (2002). Arkusz N-33-128-B

Międzychód. Główny Urząd Geodezji i Kartografii. Warszawa.

Hydrographic Map of Poland (Mapa Hydrograficzna Polski) 1:50 000 (2005). Arkusz N-33-128-B

Międzychód. Główny Urząd Geodezji i Kartografii. Warszawa.

Map of Hydrographic Division of Poland (Mapa Podziatu Hydrograficznego Polski MPHP) (19972003). Instytut Meteorologii i Gospodarki Wodnej. Warszawa.

VMapL2 (2003), Główny Urząd Geodezji i Kartografii, Zarząd Geografii Wojskowej. Warszawa.

Topographic Database Objects (Baza Danych Obiektów Topograficznych - BDOT) (2013), Główny Urząd Geodezji i Kartografii. Warszawa.

Atlas of Polisch Lakes (Atlas jezior Polski) (1996). J. Jańczak. ed. IMGW, Bogucki Wydawnictwo Naukowe. Poznań. 